\title{
Tibori Timea
}

\section{Dr. KÁRPÁtI ZolTÁN TUdOMÁNYOS FŐMUNKATÁRS EMLÉKEZETE \\ (2019. 02. 08.)}

\section{DOI 10.35402/kek.2019.1.13}

\begin{abstract}
A búcsúzás fontos és sokszor jelentéktelennek tűnő emlékeket hoz felszínre, eltűnődünk, milyennek ismertük, ismertük-e elég mélyen, lényegileg azt a személyt, akitől többé már semmit sem tudunk megkérdezni. Állunk megilletődve a ravatalánál, s nekünk, akik kollégái, barátai voltunk Kárpáti Zolinak máris felsejlik kedves mosolya, érdeklődő kérdéseinek sora. Öröm volt találkozni vele, jókedve, figyelmessége hamar eloszlatta a körülötte lévők borús hangulatát, igyekezett megosztani szakmai, emberi dilemmáit, kutatási terveit, eredményeit. Szívesen mesélt a külföldi és a hazai partnerekkel végzett munkáiról, különösen a felnőttoktatás fejlesztéséről. Éppúgy használta kutatásaiban a friss hazai és nemzetközi kutatási eredményeket, mint ahogy sokat merített a felsőoktatási tapasztalataiból. Integratív személyiség volt.
\end{abstract}

Ha nem is a teljesség igényével, de néhány fontos állomása oktatói-kutatói pályájának:

1968 óta volt a Magyar Tudományos Akadémia Szociológiai Kutató Intézetének (korábban csoportjának) munkatársa, 1986 óta főmunkatársa, miután a szociológia tudomány kandidátusa lett. 1998-tól az MTA Köztestületének tagja. 2004-től a Budapesti Gazdasági Főiskolán főigazgató helyettese, ill. oktatója volt kutatói tevékenysége mellett.

Mindezzel párhuzamosan 8 külföldi (európai és amerikai) és 4 hazai tudományos társaságban aktív szerepet töltött be.

Szakértői tevékenységet végzett hazai és külföldi kutató, oktató, szociális és állami intézmények és vállalatok számára (többek között a Budapesti Gazdasági Főiskola, TUNGSRAM, Budapesti Várostervező Intézet, Építési és Városfejlesztési Minisztérium, Miniszterelnöki Hivatal, szociális ellátó és gondozó intézmények, városi és falusi önkormányzatok, USA Munkaügyi Minisztérium, Európa Tanács).

27 jelentős hazai és nemzetközi kutatásban vett részt mint vezető, vagy társkutató (többek között: PHARE, OTKA, Magyar Népfőiskolai Társaság, Soros Foundation, IREX, PROFMEX-UCLA / USA/, European Assotiation for the Education of Adult, University of Edinburgh /UK/, CNRS /Paris/.

\section{Kutatási területei:}

társadalmi - és területi egyenlőtlenségek, urbanizáció, város- és faluszociológia, életmód és életvitel, szociális ellátás, szociálpolitika, hátrányos helyzet és felzárkóztatás, szakképzés és felnőttképzés, iskolai demokrácia.

\section{Oktatói pályájának rövid összefoglalása:}

9 föiskolai és egyetemi oktatóhelyen tanított, mint föiskolai és egyetemi tanár, köztük 3 külföldi egyetemen (McMaster University, Hamilton I Kanada/, The University of Connecticut, Storrs / USA/, Virginia Polytechnic Institute and State University, Balcsburg /USA/. Az oktatási területek megegyeznek a kutatási területekkel.

Tevékenységének fö elve a kutatás és oktatás összekapcsolása, a tudományos eredmények hasznosítása az oktatásban, a kompetencia és jártasság fejlesztése a társadalmilag hátrányos helyzetű rétegeknél, az aktív állampolgárság kibontakoztatása.

Közel félszáz hazai és nemzetközi publikáció szerzője.

Mindezt tekinthetjük egy érdekes, kihívásokkal teli, összetett értelmiségi pályának. A búcsúzáskor azonban a személyes élményeké az elsőbbség. Beszélgetéseink során gyakran irodalmi, művészeti példákat hoztunk annak igazolására, hogy milyen fontosnak tartjuk a különféle tudások adaptálását a magyar viszonyokra. Számos alkalommal idézte József Attilát, nemcsak verseit, hanem prózáját is. Megtaláltam az egyik általa hivatkozott forrást:

„....Nem értem, hogy miért volna alacsonyrendü a játék, a gyermekek öröme. Én boldog pillanataimban gyermeknek érzem magamat, $s$ akkor derüs a szívem, ha munkámban játékot fedezek fel. Félek a játszani nem tudó emberektől, és mindig azon leszek, hogy az emberek játékos kedve ne lan- 
kadjon, hogy azok a szükös életfeltételek, amelyek a játék kedvét és lehetőségét szegik, megszünjenek...

A költő alkot, és ez nem jelent kevesebbet, mint hogy alakítja a világot, az emberi világot, az emberséget, azoknak a segítségével, akik a társadalmi munkamegosztás révén mással vannak elfoglalva, úgy osztoznak a költő tevékenységében, hogy müvét szeretettel veszik magukhoz. mert a mü nem annyira a művész, mint inkább azok által él, akik szeretik a művészetet és azért szeretik, mert keresik benne az emberséget".

Kedves Barátunk, Kárpáti Zoltán, mi, akik búcsúzunk tőled, elmondhatjuk: megtaláltuk benned az emberséget.

\section{Kárpáti Zoltán válogatott publikációi Könyvek}

2007 Social Policy (Szociálpolitika), revised 2. edition, university textbook. St. Steven University, Gödöllő, 280 old.

2003 Learning Mall, Report on the TEMPUS projects on socially excluded adult learners, carried out in ten CEE countries, co-author, Budapest-Brussels, 50 old.

2000 The Sociology of Economy (Gazdaságszociológia, textbook), Budapest Business School, Budapest, 120 old.

Social Policy (Szociálpolitika) /co-authored with Zsuzsa Hantó/ PHARE Publications, St. Steven University, Gödöllő. 286 old.

The Changing Rural Society (A vidéki társadalom átalakulása). /edited and co-authored/ PHARE Publications, St. Steven University, Gödölló. 300 old.

1997 Social and Regional Processes in the 1990'ies in Hungary (Társadalmi és területi folyamatok az 1990-es évek Magyarországán /edited and co-authored/, Hungarian Academy of Sciences, Budapest, 297 old.
Social Conditions and Social Policy (Szociális helyzet és szociálpolitika)/co-authored with Zsuzsa Hantó/, Human Resources Foundation, Budapest, 267 old.

Social Policy (Szociálpolitika), University Text-Book (157 p.) and University Reader (330 pp.) (Co-authored with Zsuzsa Hantó), The University of Gödöllo”

1994 The Social Map of the City of Szombathely (Szombathely szociális térképe), Szombathely-Budapest, 98 pp. and app.

1985 Az urbanizációs folyamat társadalmi és gazdasági meghatározói. Munkások munka- és lakáspiaci magatartása. /Social and economic determinants in the urbanization process. Workers' attitudes on the labour and housing market./ PhD dissertation 219 old. Budapest: Institute of Sociology, /HAS/

1981 /with Zs. Hanto/, Ipari munkások életmódja a pécsi agglomerációban /Industrial workers' way of life in the urban region of the city of Pécs/, 207 p. Pécs: Transdanubian Research Institute, HAS

1978 /with L. Kulcsár/, Szövetségi politika. I Alliance policy/ 85 p. Budapest: Research Center of Mass Communication

\section{Könyvfejezetek}

2001 An Outline of the New Welfare Policy in Hungary. (Co-authored with Zsuzsa Szeman) In: C. Asphalter (ed.) Welfare Policies of the World (Australia)

2000 Where Rural Society is Heading? (Merre tart a vidéki társadalom?) In: The Changing Rural Society

1998 Region, Self-Government, Society (Régió, önkormányzat, társadalom). In: Alma Mater, Budapest Business School Vol. I.

1997 The Regional Dimension of the Systemic Change (Rendszerváltás térmetszetben). In: Social and Regional Processes in the 1990'ies 
Regional Inequalities, Civil Society and Local Election In: Political Stability in Eastern Europe. (eds. Jack Bielasiak and Krzistof Jasziewicz), Warsaw University

1993 The Regional Aspects of the Social Crisis and Unemployment (Regionális szempontok a válság és munkanélküliség értékeléshez) In: Új exodus /Ed.: Vera Gáthy/ Hungarian Academy of Sciences

1992 Regional Inequalities and the Perspective of Self-Government (A területi egyenlőtlenségről és az önkormányzat lehetőségeiről) In: Leltár /Ed. Vera Gáthy/ Hungarian Academy of Sciences

The Chance of Embourgeoisment in a Middle Town: The Case of Szombathely. (A polgárosodás esélyei egy középvárosban: Szombathely) In: Középvárosok a mérlegen. /Ed. Imre Kovach/, Hungarian Academy of Sciences

1991 History, Life History and Communication. In: Methods for Study of Changing Forms of Life. /Ed. Ulla Björnberg/, European Coordination Centre for Research and Documentation in Social Sciences, Vienna, Austria

Embourgeoisement and its environment (A polgárosodás és környezete) In: Pesti Hírlap, 22 Nov. 1991

Politics and Environment (Politika és környezet). In: Pesti Hírlap, 27 Sept. 1991

Embourgeoisment and Urbanisation (Polgárosodás és városszerkezet) In: Társadalomkutatás, October 1991

1990 Fribet och dubbelarbete hotar ungersk halsa. Social och ekonomisk kris i Östeuropa (Freedom, Work, Health - Social and Economic Crisis in Eastern Europe/, Vigör, 1990 No.1, Stockholm
1986 Peripheral Settlements in Hungary. The Example of Baranya Country. pp. 128134. /Gy. Enyedi and J. Veldman, eds./, Rural Development Issues. In: Industrialized Countries. Budapest-Utrecht: Regional Research Centre

1984 Települési helyzet és az életkörülmények. I Habitation and life conditions/, pp. 140163. /M. Szántó ed./ Hogyan élünk? /How do we live?/, Budapest: The Publishing House of Economics and Law

1984 Dilemmák a falufejlesztésben. Demokratikus paternalizmus vagy a démosz kraciája? /Dilemmas in the village development. Democratic paternalism or rules by the demos?/ Új Forrás, Vol. XVI. No. 4., pp. 36-38.

Társadalmi problémák egy újonnan épült városi negyedben. /Social tensions in a newly built urban district/, Magyar Épitömüvészet, 1984, No. 2., pp. 22-VIII.

1983 Ipari tevékenység a dorogi járás mezőgazdasági termelö-szövetkezeteiben. /Industrial auxiliaries of agricultural cooperatives in the Dorog district/, Új Forrás, Vol. XV. No. 2., pp. 41-63.

/with Zs. Hanto/ „Urbanizáció, elosztási politika és helyi hatalom" /Urbanization, allocation management an local power/, pp. 53-72. In /A. Bőhm, L. Pal eds./, Helyi közösségek I. Hipotézisek - kutatási módszerek /Local communities I. Hypotheses research methods/. Budapest: Social Science Institute, CC HSWP

1982 Methodological uses of life history approach in a Hungarian survey in mobility and urbanization. pp. 133-248. In: /D. Bertaux ed./, Biography and society. The life history approach in the social sciences. SAGE Studies in history approach. Volume 23./ London: SAGE Publications 
/with Zs. Hanto/ Településszerkezet és az életkörülmények a Baranya megyei aprófalvas régióban. /Settlement structure and life conditions in a region of small villages in Baranya county/, pp. 289-306. In: A.Vágvölgyi ed. A falu a mai magyar társadalomban. I The village in the contemporary Hungarian society/. Budapest: The Publishing House of the Hungarian Academy of Sciences

/with Zs. Hanto/ A városi agglomeráció szociológiai vizsgálatának módszerei. /Methods of sociological resarch in urban regions/ pp. 139-166. In: J. Rechnitzer ed. Vonzáskörzetek és agglomerációk. /Attraction zones and agglomerations/ Budapest: The Publishing House of the Hungarian Academy of Sciences

1978 /with Zs. Hanto and A. Vágvölgyi/ The development of settlement structure in Hungarian villages. pp. 134-159. In: /T. Huszár, K. Kulcsár, A. Szalai eds. /Hungarian society and Marxist sociology in the nineteenseventies. Budapest: Corvina

1981 Elsőgenerációs ipari munkások foglalkozási mobilitása. /Occupational mobility of firstgeneration industrial workers./ Területi $\mathrm{Ku}$ tatások, 1981, No. 4., pp. 56-70.

1972 Regionális egyenlőtlenségek és az életmód urbanizációja. /Regional disparities and the urbanization of ways of life./ Szociológia, Vol. III. No. 4., pp. 506-528.

1969 /with S. Radnóti/ Egy vitastílusról. / Comments on debate on Marx, I./, Valóság, Vol. XII. No. 6., pp. 103-106.

/with S. Radnóti/ Egy vitastílusról. / Comments on a debate on Marx, II. Magyar Filozófiai Szemle, Vol. XIII. No. 5., pp. 985990

\section{Kutatási jelentések}

1993 Marginalizálódás és életstratégiák a gazdasági és társadalmi átmenet idöszakában. Kutatási jelentés. 31 old.

1991 Városszerkezet és a polgárosodás esélyei. I Urbanisation and the Chance of a New Civil Life/, Institute of Sociology, Hungarian Academy of Sciences. 83 p.

1989 Szombathely urbanisztikai és társadalmi szerkezete /Urban and Social Structure of the Town of Szombathely/ Part No. 1. HAS Institute of Sociology, Budapest.

1984 A szocializmuskép változásai az MKP és az MSZMP napilapjában, 1945-1983. Összefoglalás. /Changes in socialism images in the official newspaper of the HCP and HSWP, 1945-1983. Summary chapter/, 28 pp. /Content analysis sponsored by the Research Center of Mass Communication/, Budapest

1983 Társadalompolitika és falufejlesztés. /Social policy and rural development/. 14 pp.

A falusi lakásépités társadalmi feltételei. I Social conditions and rural housing/, 103 pp. /Theoretical preliminaries to a survey sponsored by the Ministry of Construction and Urban Development/, Budapest

Szuburbanizáció a Dunántúlon: Kaposfüred esete /Suburbanization in Transdanubia: the case of Kaposfüred/, 66 pp.

/Empirical study sponsored by the Research Institute of Planning, Construction and Housing Development/, Budapest

Lakásigények és lakásmobilitás Pécsett. /Housing aspirations and housing mobility in the citys of Pécs/, 148 pp. /Empirical survey sponsored by the South-Transdanubian Planning Institute/, Pécs

Városfejlesztés és forráspolitika: Tapolca esete. /Urban renewal and resource maganement: the case of Tapolca/, 29 pp. /Research sponsored by the Research Institute for Services/, Budapest 
Hogyan valósulnak meg a tervek? Esetek a regionális és lakáspolitikából. /How do plans become reality? Case studies in regional and housing policy/, $102 \mathrm{pp}$. /Research sponsored by the Institute of Urban Planning/, Budapest

1982 Döntési folyamatok elemzése a falufejlesztésben. /Analysis of decision making in community development/. 46 pp. /Empirical study sponsored by the Research Institute for Services/, Budapest

1978 Személyzeti kiválasztás és politika a közigazgatásban. /Personnel selection and management in public administration/. 76 pp. / Research sponsored by the Trade Union of State Employees/, Budapest.

A szövetségi politika a sajtóban. Management of allience policies as reflected in the press./ 30 pp. /Content analysis sponsored by the Research Center of Mass Communication/, Budapest
1976 Akadémiai kutatók életstílusa és kulturális magatartása. /Lifestyles and cultural attitudes of academic intellectuals/. 109 pp. /Investigation sponsored by the Institute of Physics, HAS/ Budapest

1974 Interjúk falusi vezetökkel a pécsi városi régióban. Empirikus módszerek és kutatási hipotézisek. /Interviews with village leaders in the region of the city of Pécs. Empirical methods and research hypotheses./ 83 pp. /Research sponsored by the Transdanubian Research Institute, HAS/, Pécs

1968 Az esztétikai befogadás társadalmi problémái I. Kantnál és F. Schillernél. /Social problems of the aesthetic perception in I. Kant and F. Schiller/. 79 p. 